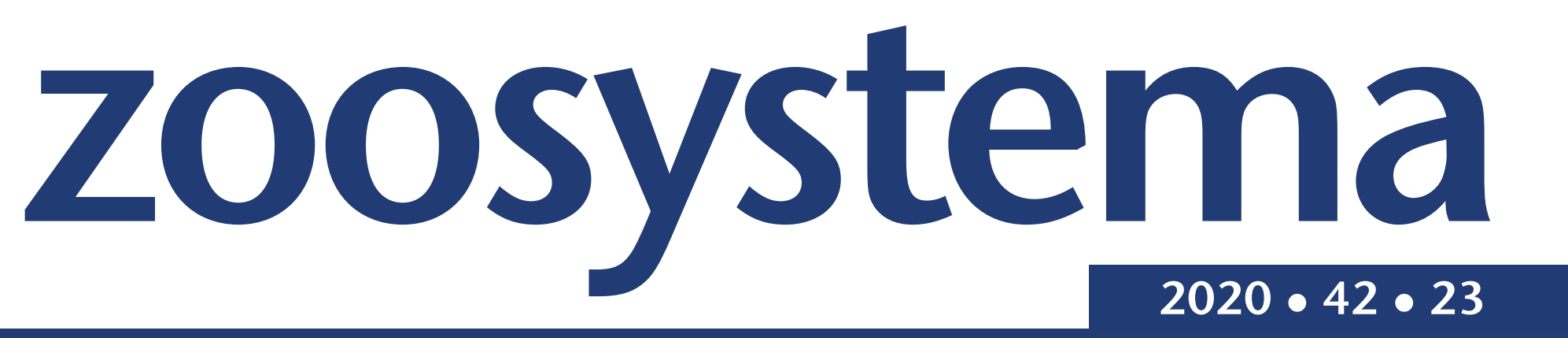

\title{
Nomenclatural consequences of the Oculudentavis khaungraae case, with comments on the practice of 'retraction' of scientific publications
}
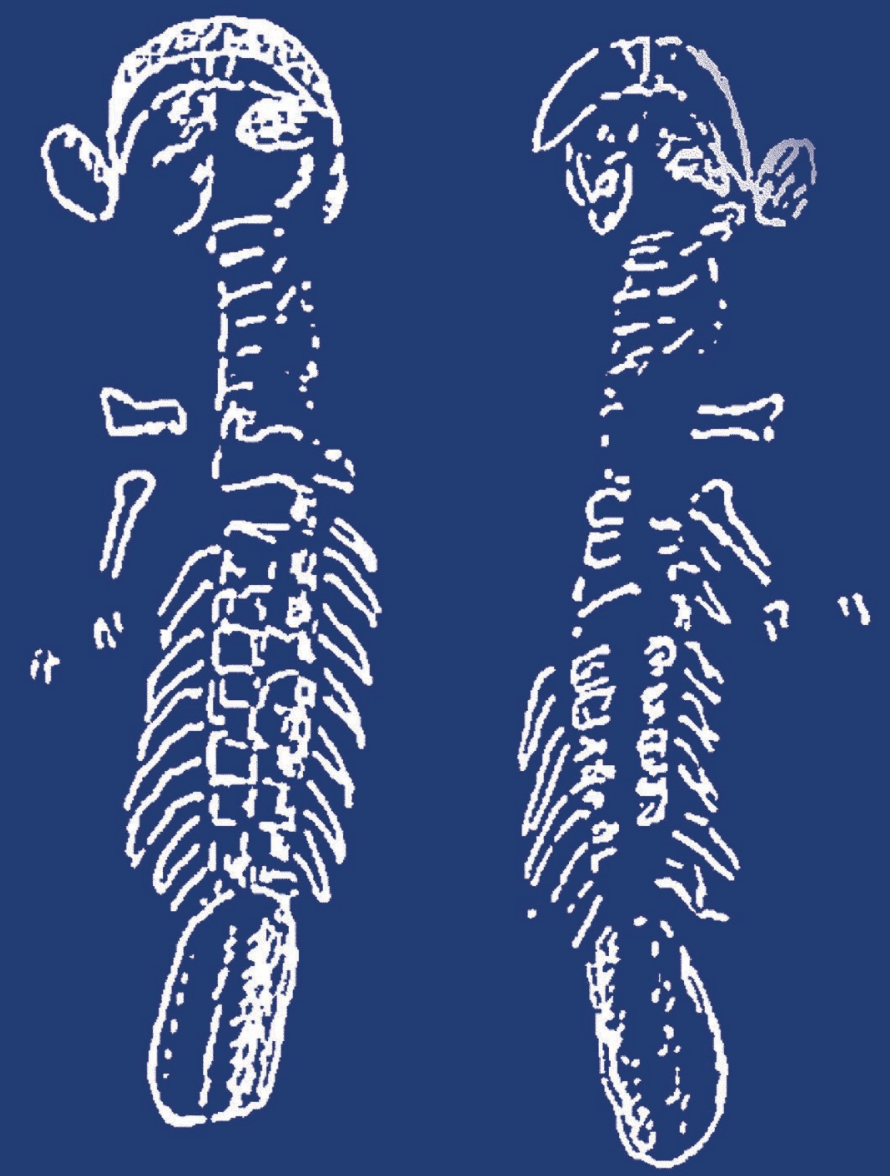

Alain Dubois 
DiRECTEUR de LA PUBLICATION / PUBLICATION DIRECTOR: Bruno David

Président du Muséum national d'Histoire naturelle

RÉDACTRICE EN CHEF / EDITOR-IN-CHIEF : Laure Desutter-Grandcolas

AsSISTANTE DE RÉDACTION / AsSISTANT EDITORS: Anne Mabille (zoosyst@mnhn.fr)

Mise en PAge / PAge Layout: Fariza Sissi

COMITÉ SCIENTIFIQUE / SCIENTIFIC BOARD:

James Carpenter (AMNH, New York, États-Unis)

Maria Marta Cigliano (Museo de La Plata, La Plata, Argentine)

Henrik Enghoff (NHMD, Copenhague, Danemark)

Rafael Marquez (CSIC, Madrid, Espagne)

Peter Ng (University of Singapore)

Norman I. Platnick (AMNH, New York, États-Unis)

Jean-Yves Rasplus (INRA, Montferrier-sur-Lez, France)

Jean-François Silvain (IRD, Gif-sur-Yvette, France)

Wanda M. Weiner (Polish Academy of Sciences, Cracovie, Pologne)

John Wenzel (The Ohio State University, Columbus, États-Unis)

COUVERTURE / COVER:

Original figure of the holotype of Boomgardia salamandriformis Huene, 1948, described as a fossil Urodele, but based on a fossil Arthropod according to Herre (1950).

Herre W. 1950. - Der derzeitige Stand unseres Wissens über die fossilen Urodelen, zugleich einige kritische Bermerkungen über Boomgardia

salamandriformis v. Huene. Neues Jahrbuch für Geologie und Paläontologie 1: 19-25.

Huene F. F. von 1948. - Ein echter Urodele aus dem unteren Dogger. Neues Jahrbuch für Geologie und Paläontologie, Monatshfete, (Abteilung B: Geologie -

Paläontologie), Stuttgart: 33-39.

Zoosystema est indexé dans / Zoosystema is indexed in:

- Science Citation Index Expanded (SciSearch $\left.{ }^{\circledR}\right)$

- ISI Alerting Services ${ }^{\circledR}$

- Current Contents ${ }^{\circledR}$ / Agriculture, Biology, and Environmental Sciences ${ }^{\circledR}$

- Scopus ${ }^{\circledR}$

Zoosystema est distribué en version électronique par / Zoosystema is distributed electronically by:

- BioOne ${ }^{\circledR}$ (http://www.bioone.org)

Les articles ainsi que les nouveautés nomenclaturales publiés dans Zoosystema sont référencés par /

Articles and nomenclatural novelties published in Zoosystema are referenced by:

- ZooBank ${ }^{\circledR}$ (http://zoobank.org)

Zoosystema est une revue en flux continu publiée par les Publications scientifiques du Muséum, Paris

Zoosystema is a fast track journal published by the Museum Science Press, Paris

Les Publications scientifiques du Muséum publient aussi / The Museum Science Press also publish: Adansonia, Geodiversitas, Anthropozoologica,

European Journal of Taxonomy, Naturae, Cryptogamie sous-sections Algologie, Bryologie, Mycologie, Comptes Rendus Palevol

Diffusion - Publications scientifiques Muséum national d'Histoire naturelle

CP 41 - 57 rue Cuvier F-75231 Paris cedex 05 (France)

Tél.: 33 (0)1 40794805 / Fax: 33 (0)1 40793840

diff.pub@mnhn.fr / http://sciencepress.mnhn.fr

(C) Publications scientifiques du Muséum national d'Histoire naturelle, Paris, 2020

ISSN (imprimé / print): 1280-9659/ ISSN (électronique / electronic): 1638-9395 


\section{Nomenclatural consequences of the Oculudentavis khaungraae case, with comments on the practice of 'retraction' of scientific publications}

Alain Dubois Institut de Systématique, Evolution, Biodiversité (ISYEB) Muséum national d'Histoire naturelle CNRS, Sorbonne Université, EPHE, Université des Antilles Reptiles \& Amphibiens, CP 3025 rue Cuvier 75005 Paris (France) adubois@mnhn.fr

KEY WORDS

Nomenclatural availability, retraction of publication, International Commission on Zoological Nomenclature,

Plenary Power history of science, denialism, scientific publications.

MOTS CLÉS Disponibilité nomenclaturale, rétractation de la publication,

Commission Internationale de Nomenclature Zoologique, Pleins Pouvoirs, histoire des sciences, dénégation, publications scientifiques.
urn:Isid:zoobank.org:pub:313D14B0-D061-4827-AC29-11B272E1C6B4

Dubois A. 2020. - Nomenclatural consequences of the Oculudentavis khaungraae case, with comments on the practice of 'rectraction' of scientific publications. Zoosystema 42 (23): 475-482. https://doi.org/10.5252/zoosystema2020v42a23. http://zoosystema.com/42/23

\section{ABSTRACT}

The recent publication in the journal Nature of a paper describing a new fossil as a 'hummingbirdsized dinosaur', followed immediately by a rebuttal stating that it was in fact a lizard, and then by the 'retraction' of the original paper, raised concerns about the nomenclatural availability of the new binomen Oculudentavis khaungraae that it introduced. It is shown here that so-called 'retraction', by authors, editors or publishers, of a controversial paper, has no bearing under the Rules of the Code on the nomenclatural availability of the paper and of the new nomina or nomenclatural acts it may contain, which can be withdrawn only by the International Commission on Zoological Nomenclature acting under its Plenary Power. It is furthermore argued that the principle of 'retraction' of scientific publications itself is anti-scientific, harmful to the history of science, and belongs in the domain of 'denialism': it should be fully abandoned by serious scientific journals.

\section{RÉSUMÉ}

Les conséquences nomenclaturales de la "rétractation" de l'article sur Oculudentavis khaungraae, et commentaires sur la pratique de la "rétractation" des publications scientifiques.

La récente publication dans la revue Nature d'un article décrivant un nouveau fossile comme un "dinosaure de la taille d'un colibri", suivie immédiatement d'une réfutation affirmant qu'il s'agissait en fait d'un lézard, puis de la "rétractation" de l'article original, a suscité des commentaires quant à la disponibilité nomenclaturale du nouveau binomen Oculudentavis khaungraae qu'il introduisait. Il est démontré ici que la "rétractation" d'une publication controversée par les auteurs, les rédacteurs ou les éditeurs n'a aucune incidence, en vertu des règles du Code, sur la disponibilité nomenclaturale du travail et des nouveaux nomina ou actes nomenclaturaux qu'il peut contenir, qui ne peuvent être invalidés que par la Commission Internationale de Nomenclature Zoologique agissant en vertu de ses Pleins Pouvoirs. Il est en outre avancé que le principe de "rétractation" des publications scientifiques est lui-même anti-scientifique, nuisible à l'histoire des sciences, et relève de la "dénégation": il devrait être totalement abandonné par les revues scientifiques sérieuses. 


\section{PRELIMINARY REMINDER}

In order to fully understand what follows, a few words are useful to remind the meaning in zoological taxonomy of the expression 'nomenclatural availability', which is sometimes mistaken for 'nomenclatural validity'. Zoological nomenclature is regulated by the International Code of Zoological Nomenclature (Anonymous 1999; 'the Code' below), which is currently under the responsibility of the International Commission on Zoological Nomenclature ('the Commission' below), and which is complied with by most zootaxonomists worldwide. Under the Rules of this Code, in order to be 'usable' in zoological nomenclature, a work (publication), a nomen (scientific name) or a nomenclatural act (e.g. a 'First Reviser action') must respect a number of conditions from the very date of its public distribution. If so, it is stated to be 'available' and if not it is 'unavailable', which means that it does not 'exist' within the realm of zoological nomenclature and should never be used as valid in any scientific publication. Under the Code, except in cases of ambiguities requiring a 'First Reviser action', the nomenclatural status of a nomen regarding its availability is fixed once and for all in the publication where it is introduced, an 'unstated' Principle of the Code which has been called "Principle of Nomenclatural Foundation" (Dubois et al. 2019). This status cannot be modified by anyone, be it its original author or editor, but only by the Commission acting under its Plenary Power (Article 81 of the Code).

As for the taxonomic allocation of a nomen, under the Code it is made exclusively by ostension through its onomatophore ('name-bearing type') and not by any 'intensional definition' of the taxon, or by its taxonomic placement in a hierarchic taxonomy or in a phylogenetic hypothesis (for details see Dubois 2011).

\section{THE OCULUDENTAVIS KHAUNGRAAE CASE}

Xing et al. (2020a) described in the journal Nature a fossil from the Cretaceous of Myanmar, a skull in amber preserved in the Hupoge Amber Museum under the number HPG 13.3, under the nomen Oculudentavis khaungraae. They considered it to be a "hummingbird-sized dinosaur" and referred it to the higher taxon 'Aves Linnaeus, 1758'.

Shortly after, Li et al. (2020), in an online unreviewed 'preprint' (which has so far remained 'unpublished' in a peerreviewed scientific periodical), provided arguments strongly suggesting that this ill-preserved specimen was not a bird, not even an archosaur, but most likely a lepidosaur and even a squamate.

In parallel, and as a result of examination of a new, undescribed specimen belonging apparently to the same species, and showing additional characters implying it is in fact a lepidosaur, on 22 July 2020 the journal Nature announced the 'retraction' of the paper by its authors (Xing et al. 2020b), and on 30 July 2020 Nature confirmed that this specimen was "probably a lizard" (Anonymous 2020).

It is important to note that the reason for retraction here was not fraud or unethical behaviour, but what has been considered major error(s) in the publication that had escaped the attention of the editor and referees of the paper.
The retraction did not suppress the article from the record. For the time being, the original article is still accessible on the Nature website, but even if it was later deleted from there, this would not mean that the paper was never published.

\section{NOMENCLATURAL IMPLICATIONS}

Immediately after publication of this 'retraction', a hot discussion developed on the social networks (e.g., http://dinosaurmailinglist.cmnh.org/, https://svpow.com/, http://list. afriherp.org/mailman/listinfo/iczn-list). Some interveners argued that, because of this retraction, this binomen (and consequently also its two constituents, its generic substantive Oculudentavis and its specific epithet khaungraae), had become nomenclaturally unavailable, in other words 'expelled' from the realm of zoological nomenclature, and therefore should not be used to designate organisms under the international Rules. Thus for example, Evangelos Vlachos wrote on 23 July 2020 in the forum http://list.afriherp.org/mailman/listinfo/ iczn-list: "Based on the current Code, I think that this name should not be considered as available, as after the retraction the work cannot be considered anymore as published for the purposes of zoological nomenclature (or for any other purposes for that matter), as it is no longer 'a public and permanent scientific record' (Art. 8.1.1)." This author suggested that the Code should be modified in order to include "a specific article on retractions that can be applied automatically" in order to 'suppress' nomina first published in works later 'retracted'.

Such an interpretation is fully wrong and this proposal is misguided. As we have seen, under the Code, once a nomen has been published in a Code-compliant manner making it available, it can be 'suppressed' (i.e., 'invalidated') only by the Commission acting under its Plenary Power. Therefore, the 'retraction' has no bearing on the nomenclatural availability of the work and of the new nomina it contains. The reference above to Article 8.1.1 is misleading, as, at the time when the original paper was published in Nature, it had indeed been "issued for the purpose of providing a public and permanent scientific record". Its 'retraction' is a subsequent event, which does not interfere with the nomenclatural status of the binomen, as under the Code this status is fixed by the "Principle of Nomenclatural Foundation".

This Principle is fully justified. What would happen if an author published a new nomen, if this nomen was used by hundreds of authors for 50 years, and if finally the author, the editor or the publisher, decided to 'retract' this paper? This would entail considerable, and entirely useless, nomenclatural instability, which would just create out of nowhere problems in communication. This is already what happens in some cases of recent decisions of the Commission to use its Plenary Power to 'suppress' some ancient taxonomic works. This problem is not very severe when this invalidation has been done long ago (as in the case of the work of Oken 1816: see Hemming 1956) and when the 'suppressed' work is not widely known in the community, but it may be a source of strong difficulties when it was recent and concerned works that had been considered available for more than two centuries, and some of their nomina used as valid in thousands 
of publications: this was the case of the works of Brisson (1762) and La Cepède (1788a-c, 1789, 1790a, b), suddenly 'suppressed' without appropriate discussion (Anonymous 1987, 1998, 2005) and without any benefit for zoological nomenclature but instead the creation ex nibilo of nomenclatural instability (see e.g. Dubois \& Frétey 2020). It would be quite inappropriate for the Commission to introduce now in the Code a provision stating that, once 'retracted', a work becomes unavailable in zoological nomenclature.

In support of their opinion that the nomen Oculudentavis khaungrade should be considered unavailable, some participants to the online discussions on this matter cited Article 8.2 of the Code, which reads: "A work that contains a statement to the effect that it is not issued for public and permanent scientific record, or for purposes of zoological nomenclature, is not published within the meaning of the Code." This citation is also irrelevant to the present discussion, as it only refers to disclaimers that appeared in the original publication where the new nomen was introduced, not in any other subsequent publication as it is the case here.

Other ill-advised considerations on this matter can be discarded. Concerning the generic substantive, this applies to the fact that the -avis suffix of the generic nomen subsequently proved to have been misleading to designate a 'non-bird'whereas Article 18 of the Code states clearly: "The availability of a name is not affected by inappropriateness (...)". As for the specific epithet, it is stated in the original work to have been derived from the name of "Khaung $\mathrm{Ra}$, who donated the specimen to the Hupoge Amber Museum", without any precision on whether this person is a woman or a man. The ending in -ae suggests it may be a woman, but if so the repetition of the letter $a$ in this nomen was not justified. Article 32.5.1 of the Code states that inadvertent errors in the formation of new nomina must be corrected, but then adds: "Incorrect transliteration or latinization, or use of an inappropriate connecting vowel, are not to be considered inadvertent errors." Thus, although both the generic substantive and the specific epithet of the new taxon were, or can be considered to have been, ill-formed, they should not be 'corrected' (see also Dubois 2018).

Another question regarding both these new (generic and specific) nomina concerns their publication date, which could have some bearing on their validity in case of subsequent discovery that one or both of them is or are synonyms of other available nomina of squamates. The pdf of the original paper of Xing et al. (2020a) is dated "11 March 2020". This is the date of public distribution of the online version of this paper. However, this paper does not include any mention that it had been pre-registered in the database Zoobank, and provided an 'Isid' identifier, as required by the 2012 Amendment of the Code dealing with electronic publication of new works, nomina and nomenclatural acts (Anonymous 2012). On page 249 of this paper, it is stated that "statements of data and code availability are available at https://doi.org/10.1038/s41586-020-2068-4”, which is just the link to the online version of the paper, but neither in this document nor in the "Supplementary information” (https://doi.org/10.5281/zenodo.3591994) mentioned on page 250 does an lsid of the paper appear-which just means that the editors and publishers of Nature do not know what the formula "code availability" means.

Therefore this paper and its two new nomina were not made nomenclaturally available through this electronic publication, but they were so through the public distribution of the paper version of number 7798 of volume 579 of Nature, which took place on 12 March 2020. In this case the difference of date between the two versions is only of one day, but in other cases it is much longer, up to several months and sometimes in different years, which suggests that online publication of a work earlier than the paper version is a bad practice which should be abandoned by taxonomists (Dubois et al. 2013, 2015a-b, 2019).

\section{NOMENCLATURAL CONSEQUENCES AND SIMILAR CASES}

The conclusion of the dicussion above is that the binomen Oculudentavis khaungraae was duly made available by Xing et al. on 12 May 2020 in the paper version of number 7798 of volume 579 of the journal Nature. This paper publication complied with the three criteria of Article 8.1 of the Code (it was issued for the purpose of providing a public and permanent scientific record; it was obtainable, when first issued, free of charge or by purchase; and it was produced in an edition containing simultaneously obtainable copies by a method that assures numerous identical and durable copies); it did not contain a statement to the effect that it was not issued for public and permanent scientific record, or for purposes of zoological nomenclature (Article 8.3), or that all or any of the nomina or nomenclatural acts in it were disclaimed for nomenclatural purposes (Article 8.4); and it was not invalidated ('suppressed') for nomenclatural purposes by the Commission through use of its Plenary Power (Articles $8.7,81)$. As for the new nomen itself, it also complied with the Code requirements: it was correctly formed under the Code's criteria (Articles 11.2-3, 11.9); it was used as valid when proposed (Article 11.5); it was accompanied by a description and a definition that stated in words characters that were purported to differentiate the taxon (Article 13.1.1); both the generic substantive and the specific epithet were made available through mention of the expression "gen. et sp. nov." (Article 13.4); the intention of the authors to establish new nomina was explicit (Article 16.1); and the new specific nomen was accompanied in the original publication by the explicit fixation of a holotype (Article 16.4.1) and the statement that this specimen was deposited in an identified collection (Article 16.4.2).

As discussed above, the nomenclatural availability of this binomen and of its two components is not affected by the 'retraction' of the paper where it was introduced. According to the Code, the taxonomic allocation of this nomen was effected through its onomatophore, the specimen HPG 15.3. As of today, no published information allows to know to which current taxon this nomen applies, but when such data are provided it will be possible to ascertain whether this specimen is indeed a squamate and to which taxon it belongs. There are only three possibilities in this respect: [P1] either it will 
be considered by taxonomists to belong in a species already known and named, and then both the generic substantive and the specific epithet of the binomen Oculudentavis khaungraae will have to be treated as invalid junior synonyms; or [P2] the species will be considered not to have yet been described but to belong in a genus already named, and then the epithet khaungraae will stand as valid but will have to be referred to the latter genus, the substantive Oculudentavis becoming an invalid junior synonym of its valid nomen; or [P3] both the genus and the species will be considered new, and this species will have to bear this binomen. From the nomenclatural point of view, the fact that this species will then have to move from the taxon Aves to the taxon Squamata is of no importance and relevance at all in this process and should not hinder it. In zoological nomenclature, the validity of a species nomen is completely independent from the higher classification of this species.

Such a situation is extremely common in zoological nomenclature. Many specific and generic nomina were made available through implementation of a Code-compliant process for this purpose (available publication, mention of characters purported to differentiate the taxon, respect of the criteria required for the formation of the nomen, etc.) but were later shown to apply to a taxon belonging in a higher taxon different from that to which they had initially been referred. This is very frequent at genus level, as shown by two examples in amphibians: in 2001, in the frog genus Philautus, 78 nominal species out of 177 (i.e. 44.1\%) had changed of generic allocation since their original description (Dubois \& Ohler 2001); and in 2012, in the order Urodela (salamanders), 201 valid species out of 693 (i.e. 29.0\%) had suffered the same fate (Dubois \& Raffaëlli 2012). Similar trends can be expected in all other zoological groups. This occurs also at all other hierarchical levels in the classification: many species or genera originally described as belonging in a family, order or class were later transferred to another taxon of this rank. This occurred under the pen of numerous authors including the most famous ones, as highlighted by the case of the genus Proteolepas, erected by Darwin (1854) for a single species that he considered to belong in the Cirripedia, a group of Crustacea currently referred to the class Maxillopoda, but which belongs in fact in the Isopoda, a group of Crustacea currently referred to the class Malacostraca (Bocquet-Védrine 1972; Dubois \& Frétey 2020).

Such cases are of course particularly frequent in paleozoology, because of the incompleteness of many fossil specimens, and more frequent in the ancient than in the recent literature. There are many such examples in herpetology. Let us just mention ten of them, by chronological order of their original publications: [E1] the 'salamander' nomen Salamandra rusconi Costa, 1851, based on a fossil skeleton of lizard (Estes 1981); [E2] the 'salamander' nomen Amphiuma norica Brunner, 1956, based on the broken anterior end of a teleost parasphenoid (Estes 1969); [E3] the 'crocodile' nomen Eridanosaurus brambillae Balsamo-Crivelli, 1864, based on a cervical vertebra of fossil rhinoceros (Steel 1973); [E4] the 'frog' nomen Rana rara Fraas, 1870 (nomen nudum), based on a tibio-fibula which probably belonged to a small mammal (Böttcher in Sanchíz 1998; Dubois et al. 2001); [E5] the nomen Hedronchus sternbergii Cope, $1877 \mathrm{a}$, originally unallocated to a higher taxon but later believed by Cope (1877b) and Hay (1902) to be referable to the chondrichthyan elasmobranchs, based on a bone initially believed to be "the crown of a young tooth" (Cope 1877a: 259) but later shown to be the anterior cotyle of a broken vertebra of salamander (Estes 1964; Dubois \& Frétey 2019); [E6] the 'caecilian' nomen Prohypogeophis turaniensis Marcus, 1945, based on a cephalopod shell (Estes \& Wake 1972); [E7] the 'salamander' nomen Boomgardia salamandriformis Huene, 1948, based on a fossil of arthropod (Herre 1950); [E8] the 'caecilian' nomen Ichthyophis muelleri Brunner, 1954, based on a fossil pectoral spine of silurid catfish (Estes \& Wake 1972); [E9] the nomina Salamandra pottensteinia Brunner, 1956, Praesalamandra goessweinsteinia Brunner, 1957, Praesalamandra sirenoides Brunner, 1957 and Salamandra perversa Brunner, 1957, based on incomplete bones which were probably broken posterior ends of teleost parasphenoids, perhaps of catfish (Estes 1981); and [E10] the 'salamander' nomen Permotriturus herrei Tatarinov, 1968, based on a fossil that was considered by Hecht (in Estes 1981) to be from a chrondrichthyan fish and is now referred to the Parareptilia Bolosauridae (Falconnet 2012)!

One of these cases prompted Dubois \& Frétey (2019) to write: "This case highlights the kind of problems that can be caused by the formal naming of taxa based on very incomplete fossils the characters and relationships of which are unknown." In many such cases, it may be justified to publish new data based on a new fossil, if this indeed allows a significant progress of knowledge, without necessarily waiting for the perfect, complete find, but in cases of strong doubt it would be much better to describe the fossil but refrain from naming it, as a nomen once published cannot be 'erased' even if it is shown to have been premature or unwarranted. In paleontology, because of the fragmentary nature of most fossils, the discovery of further specimens or a re-analysis of the original one may change the interpretation researchers had on the species within a few months. The views on the phylogenetic position of Oculudentavis has shifted rapidly, indeed, and rather radically, which sugggests that perhaps the first publication went too far and forced a position in Aves, being thus very 'interesting mediatically', despite elements which suggested a non-archosaurian allocation ( $\mathrm{Li}$ et al. 2020). But this was just an accelerated form of the widespread way paleontology works, often through zigzagging leaps. Retraction of the original work should never be an option in such cases. Regardless of the possible pressure from the journal editors to have this retraction done, paleontologists and other scientists should not support such practices. The initial article should remain as it is, progress in the understanding of Oculudentavis be acknowledged, and ultimately there will probably exist no issue than regarding the binomen Oculudentavis khaungraae as designating a lizard.

Oculudentavis khaungraae is just a newcomer in the galaxy of weird cases exemplified above: welcome to the club! Except for the nomen nudum Rana rara, all these nomina are still 
nomenclaturally available, but just had to be transferred from their original to their current higher taxonomic allocation, or considered as nomina dubia when this allocation is uncertain. Nomina dubia remain available even if they are not taxonomically allocated, but then of course they cannot be used as valid. However, this may change if their missing or unassignable holotypes or syntypes are identified (e.g., through molecular methods) or replaced by topotypical neotypes, which is an elegant way to make them 're-enter' the realm of zoological nomenclature. Despite the comments of some (e.g., Dayrat 2005), who consider nomina dubia as 'nomenclatural plagues', the provisions provided by the Code to deal with such nomina based on unidentifiable or lost specimens are excellent (Dubois 2011) and do not require the introduction of new Rules, especially concerning the 'retraction' of publications.

Some authors (e.g., Kaiser et al. 2013) consider that the practice of 'peer-review' is a strong guarantee against the publication of errors or falsifications in scientific papers, particularly in taxonomy and nomenclature. Unfortunately, this belief is not borne out by the facts. It proves to be wrong particularly regarding papers dealing with taxonomy, and among them those which contain nomenclatural acts, as very few editors of 'generalist' journals are competent in these domains. In fact, concerning taxonomic and nomenclatural papers, both following situations do occur: bad or awful papers with scientific errors published in 'famous' journals (peer-reviewed and highly ranked according to quantitative 'automatic' metrics produced by algorithms such as the well-known 'Impact Factor'), and excellent or outstanding papers published in more 'obscure' journals which do not practice real peer-review but just a review by the journal's chief editor, if the latter is a highly competent taxonomist-but the reverse of both situations also occurs. In other words, there is no correlation between the quality of taxonomic and nomenclatural papers and the rating (according to the most used metrics) of the journals where they are published. Most colleagues, when they are shown unacceptable taxonomic and nomenclatural errors published in highly ranked journals, just reply that 'to err is human' and that such facts are exceptional and not significant. However, in amphibians at least (my main domain of research), this phenomenon is not borderline and due to simple inadvertence but points to editorial incompetence, in both domains of taxonomy and of nomenclature, as shown by the various examples listed in Dubois (2003) and Dubois et al. (2013, 2018, and references therein), which appeared in various periodicals with Impact Factors straddling from low to very high.

Of course, taxonomic and nomenclatural errors are not the only ones that can occur in scientific papers. But they have a specificity. Because of the Principle of Nomenclatural Foundation, the status of a nomen or nomenclatural act is fixed once and for all in the original publication where it appeared (see Minelli 2003). Except in cases of ambiguities that can be cleared up by subsequent 'First Reviser' action, this status cannot be corrected through individual actions, even by the original author, editor or publisher, but only by the Commission acting under its Plenary Power. In order to avoid in the future potential problems like those described above, taxonomists would be well advised to refrain from publishing taxonomic papers including new nomina or nomenclatural acts in scientific journals that do practice 'retraction' of some of their publications, even if these periodicals are 'well-known' and 'highly-graded'.

\section{GENERAL COMMENTS ON THE PRACTICE OF 'RETRACTION OF PUBLICATION'}

Like all other human activities, scientific research is not a 'perfect' domain. Science progresses through the proposals of hypotheses, their testing, and, in case of refutation, their replacement by new hypotheses that will suffer the same fate. All along the history of science, errors have been published, and there is no reason why this should not continue. Some of these errors were in fact deliberate falsifications, like those of the 'Piltdown Man Affair' (Gould 1980), of the 'Midwife Toad Affair' (Aronson 1975) or of the 'Burt Affair' (Mackintosh 1995). Some of these falsifications had considerable social consequences, like the repeated famines caused by 'Lysenkoism' in the USSR and China (Joravsky 1970). But many more errors were involuntary, caused by ignorance, methodological incompetence or carelessness, misinterpretation of data, or unlucky circumstances. In other human domains, such errors may have a long or indefinite life: some people still think that the earth is flat or that the evolution of life was directed by 'intelligent design'. In science however, even if this may take decades, in most cases errors are finally discovered, rebutted and corrected.

As long as scientific publications were made on paper, in books or periodicals, the only way to correct errors was through the publication of errata, corrigenda or rebuttals. However, the original faulty publications remained available along with their refutations. This was very important, as it allowed historians of science to reconstruct, analyse and understand the evolution of ideas and practices in science and to call attention to precautions to be taken to avoid their repetition or disclose their occurrence. But a major change occurred with the onset, and the burst, of 'virtual publications' made available online, but prone to 'disappear' at any time. The 'social networks' are the paragons of this new kind of 'publications', which could be called 'provisional' or 'labile' publications: any text that is distributed online, on a blog, a website or any other application, may be withdrawn at all times, without warning, and without any long-time stocking of its content. Only a very small percentage of these ephemeral documents are stored on 'permanent' archives, and even then there is no guarantee that this storage will still exist in one or a few decades. This completely new situation in the history of science and even more largely of human culture poses considerable problems, and it is clear that few people have taken its full measure so far. Its continuation for several decades will make very difficult, and even impossible in many cases, the reconstruction of the history of science, of culture and of societies.

If this phenomenon was restricted to the 'social networks', its impact would remain limited. But it has progressively spread into the realm of scientific publications, which is 
much more worrying. There may be several reasons for the new practice of 'retractions' of scientific papers or books first published online (Van Noorden 2011), ranging from the mere discovery by an author of errors in the data, interpretations or conclusions of a work, then to the publication by other authors of rebuttals to the original work, leading the author or the publisher to withdraw the latter for fear that it could contribute to a 'bad image' of the work of the author or of the periodical concerned - to the strong pressure exerted by industrials or lobbies on the publishers, in domains like medicine, pharmaceutics, agronomy or industry, in order to protect their reputation and profits, as shown by several recent affairs that had strong media impacts. Progressively, retraction of publications has become a widespread practice in scientific edition. A website (https://retractionwatch.com/) is now devoted to its promotion and support.

In case of discovery of errors in scientific publications, the recent trend to replace the public publication of new papers explaining these mistakes (as errata, corrigenda and rebuttals), without 'suppressing' the faulty or imperfect work, by the 'retraction' of the latter, is in fact an insult to scientific practice and deontology and to the history of science. In science, what has been published has been published and cannot be 'nullified'. In history, the strong term 'historical negationism', which means the deliberate negation, distorsion or falsification of historical facts and documents (e.g., photographs), is unanimously rejected as unacceptable, especially when it concerns war crimes and crimes against humanity. Undoubtedly, the withdrawal of scientific publications does not have the same severity and has less harmful social and ideological consequences, but it should be submitted to the same rejection by the scientific community. It amounts to a falsification of history and to a refusal of reality for which the term 'denialism' (as defined e.g. by Fassin 2007) is appropriate. In many cases, it does not help the progress of scientific knowledge but its function may be to try and save the image of periodicals and the reputation of authors, or of referees and editors who have not carried out properly their work of 'peer-review', possibly in order to comply with the growing strong pressure for speed of publication - at the expense of scientific seriousness and accuracy.

For the reasons given above, the rejection of the practice of retraction of scientific publications is particularly relevant for publications containing nomenclatural acts. The idea that the Code should be modified in order for 'retracted works' to be considered nomenclaturally unavailable should be banned from the start and should not be supported by responsible working taxonomists. Such a decision would be a very dangerous precedent in the direction of a 'de-scientification' of zoological nomenclature.

\section{ACKNOWLEDGEMENTS}

I am very grateful to Antoine Louchart (Villeurbanne), Alessandro Minelli (Padova) and Laure Desutter (Paris) for their insightful comments on the original manuscript, and to Thierry Frétey (Saint-Maugan), Annemarie Ohler (Paris), Mark Young (Edinburgh) and Marie-Astrid Angel (Paris) for their help in bibliographical research.

\section{REFERENCES}

ANONYMOUS [INTERNATIONAL COMMISSION ON ZOOLOGICAL NOMENClaturE] 1987. — Opinion 1463. De Lacépède, 17881789, Histoire Naturelle des Serpens and later editions: rejected as a non-binominal work. Bulletin of zoological Nomenclature 44 (4): $265-267$

ANONYMOUS 1998. - Opinion 1894 Regnum Animale ..., Ed. 2 (M.J. Brisson, 1762): rejected for nomenclatural purposes, with the conservation of the mammalian generic names Philander (Marsupialia), Pteropus (Chiroptera), Glis, Cuniculus and Hydrochoerus (Rodentia), Meles, Lutra and Hyaena (Carnivora), Tapirus (Perissodactyla), Tragulus and Giraffa (Artiodactyla). Bulletin of zoological Nomenclature 55 (1): 64-71.

ANONYMOUS [INTERNATIONAL COMMISSION ON ZOOLOGICAL NOMENCLATURE] 1999. - International code of zoological nomenclature. Fourth edition. International Trust for zoological Nomenclature, London: i-xxix + 1-306.

ANONYMOUS [INTERNATIONAL COMMISSION ON ZOOLOGICAL NOMENClatURE] 2005. - Opinion 2104 (Case 3226). Lacepède, B. G. É. de la V., 1788, Histoire Naturelle des Quadrupèdes Ovipares: rejected as a non-binominal work. Bulletin of zoological Nomenclature 62 (1): 55.

ANONYMOUS [INTERNATIONAL COMMISSION ON ZOOLOGICAL NOMENCLATURE] 2012. - Amendment of Articles 8, 9, 10, 21 and 78 of the International Code of Zoological nomenclature to expand and refine methods of publication. Bulletin of zoological nomenclature 69 (3): 161-169. https://doi.org/10.21805/bzn. v69i3.a8.161

ANONYMOUS 2020 - World's smallest dinosaur is probably a lizard. Nature 583: 665.

Aronson L. R. 1975. - The case of The Case of the Midwife Toad. Behavior Genetics 5: 115-125. https://doi.org/10.1007/ BF01066805

BALSAMO-CRIVELLi 1864. - Di una vertebra fossile di rettile trovata nelle ghiaje del Po. Atti Società italiana di Scienze naturali, Milano 7: 210-212.

BOCQUET-VÉDRINE J. 1972. — Suppression de l'ordre des Apodes (Crustacés Cirripèdes) et rattachement de son unique représentant, Proteolepas bivincta, à la famille des Crinoniscidae (Crustacés Isopodes, Cryptonisciens). Comptes rendus de l'Académie des Sciences (D) 275: 2145-2148, pl. 1.

BRISSON A. D. 1762. - Regnum animale in classes IX. Distributum, sive synopsis methodica sistens generalem Animalium distributionem in Classes IX, \& duarum primarum Classium, Quadrupedum scilicet \& Cetaceorum, particularem divisionem in Ordines, Sectiones, Genera \& Species. Cum brevi cujusque speciei descriptione, citationibus auctorum de iis tractantium, nominibus eis ab ipsis \& nationibus impositis, nominibusque vulgaribus. Theodorum Haak, Lugduni batavorum: [i-vi] + 1-296. https://hdl.handle. net/2027/chi.086118302

BRUNNER 1954. - Das Fuchsloch bei Siegmannsbrunn (Oberfr.) (Eine mediterrane Riß-Würm-Fauna). Neues Jahrbuch für Geologie und Paläontologie, Abhandlungen, Stuttgart, 100: 83-118. [Not seen]. BRUNNER 1956. - Nachtrag zur Kleinen Teufelshöhle bei Pottenstein (Oberfranken). Ein Übergang von der letzten interglaziale RissWürm-Warm-fauna zur Würm I-Kaltfauna. Neues Jahrbuch für Geologie und Paläontologie, Monatshefte, Stuttgart, 1956: 75-100.

BRUNNER G. 1957. — Die Breitenberghöhle bei Gössweinstein /fr. Eine Mindel- Riß-und eine post-glaziale Mediterran-Fauna. Neues Jahrbuch für Geologie und Paläontologie, Monatshefte, Stuttgart, 1957: 352-378 + 385-403. [Not seen]. 
Cope E. D. 1877a. - Descriptions of some vertebrate remains from the Fort Union beds of Montana. Proceedings of the Academy of natural Sciences of Philadelphia, '1876', 28: 248-261.

Cope E. D. 1877b. - On some extinct Reptiles and Batrachia from the Judith River and Fox Hills beds of Montana. Proceedings of the Academy of natural Sciences of Philadelphia, '1876', 28: 340-359.

CosTA O. G. 1851. - Cenni interno alle scoperte fatte nel Regno riguardanti la paleontologia nel corso dell'anno. Letti all'Accademia pontaniana nella tornata del 31 agosto 1851. Filiatre Sebezio, Napoli: 1-12. [Not seen].

DARWIN C. 1854. - A.monograph on the subclass Cirripedia of all the species. Ray Society, London: i-viii + 1-684.

DAYRAT B. 2005. - Towards integrative taxonomy. Biological Journal of the Linnean Society 85: 407-415. https://doi.org/10.1111/j.10958312.2005.00503.x

Dubois A. 2003. - The relationships between taxonomy and conservation biology in the century of extinctions. Comptes rendus Biologies 326 (suppl. 1): S9-S21. https://doi.org/10.1016/ S1631-0691(03)00022-2

DuBoIs A. 2011. - The International Code of Zoological Nomenclature must be drastically improved before it is too late. Bionomina 2: 1-104. https://doi.org/10.11646/bionomina.2.1.1

DuBoIs A. 2018. - The correct spelling of the nomen Nyctimystes cheesmani Tyler, 1964 (Amphibia, Anura), with some comments on Latin grammar and the Rules of the Code. Alytes 35 (1-4): 75-84.

Dubois A., Bauer A. M., Ceriaco L. M. P., Dusoulier F., Frétey T., Lobl I., Lorvelec O., Ohler A., Stopiglia R. \& Aescht E. 2019. - The Linz Zoocode project: a set of new proposals regarding the terminology, the Principles and Rules of zoological nomenclature. First report of activities (2014-2019). Bionomina 17: 1-111. https://doi.org/10.11646/bionomina.17.1.1

Dubois A., Bour R. \& Ohler A. 2015a. - What is an online 'preliminary version' of a publication in the meaning of Article 9.9 of the Code? One more step on the trail of the Asian elephant. Bulletin of zoological Nomenclature 72 (1): 6-18.

Dubois A., Bour R. \& OHLER A. 2015b. - Nomenclatural availability of preliminary electronic versions of taxonomic papers: in need of a clear definition. Bulletin of zoological Nomenclature 72 (3): 252-265.

Dubois A., Crochet P.-A., Dickinson E. C., Nemésio A., Aescht E., Bauer A. M., Blagoderov V., Bour R., de Carvalho M. R., Desutter-Grandcolas L., Frétey T., Jäger P., Koyamba V., LaVilla E. O., LÖBl I., Louchart A., Malécot V., SChatz H. \& OHLer A. 2013. - Nomenclatural and taxonomic problems related to the electronic publication of new nomina and nomenclatural acts in zoology, with brief comments on optical discs and on the situation in botany. Zootaxa 3735 (1): 1-94. https://doi. org/10.11646/zootaxa.3735.1.1

DuBOIS A. \& FrÉTEY T. 2019. - The status of the generic nomina Hedronchus Cope, 1877, Hemitrypus Cope, 1877 and Scapherpeton Cope, 1877 and of the related specific nomina (Amphibia, Urodela). Alytes 37 (1-2): 67-72.

DuBOIS A. \& FRÉTEY T. 2020. - Herpetological higher taxa nomina. 4. Gymnophiona Rafinesque-Schmaltz, 1814. Bionomina, in press.

Dubois A., Frétey T. \& OHLER A. 2018. - The Relictus case: it is high time that taxonomists follow the Code's requirements for nomenclatural availability and validity of new zoological nomina. Bionomina 13:51-64. https://doi.org/10.11646/bionomina.13.1.4

Dubois A., MATsui M. \& OHLER A. 2001. - A replacement name for Rana (Paa) rara Dubois \& Matsui, 1983 (Amphibia, Anura, Ranidae, Raninae). Alytes 19 (1): 2-4.

Dubois A. \& Ohler A. 2001. - Systematics of the genus Philautus Gistel, 1848 (Amphibia, Anura, Ranidae, Rhacophorinae): some historical and metataxonomic comments. Journal of South Asian natural History 5 (2): 173-186.

Dubois A. \& RAFFAËLLI J. 2012. - A new ergotaxonomy of the order Urodela Duméril, 1805 (Amphibia, Batrachia). Alytes 28 (3-4): 77-161.
EsTES R. 1964. - Fossil vertebrates from the late Cretaceous Lance formation, eastern Wyoming. University of California Publications in geological Sciences 49: 1-180. [Not seen].

ESTES R. 1969. - The fossil record of amphiumid salamanders. Breviora 322 : 1-11.

Estes R. 1981. - Gymnophiones, Caudata. In: P. Wellnhofer (ed.), Handbuch der Paläoherpetologie, Teil 2, Gustav Fischer, Suttgart \& New York: i-xv + 1-115.

ESTES R. \& WAKE M. H. 1972. — The first fossil record of caecilian Amphibians. Nature 239:228-231. https://doi.org/10.1038/239228b0

FALCONNET J. 2012. - First evidence of a bolosaurid parareptile in France (latest Carboniferous-earliest Permian of the Autun basin) and the spatiotemporal distribution of the Bolosauridae. Bulletin de la Société géologique de France 183 (6): 495-508. https://doi. org/10.2113/gssgfbull.183.6.495

FASSIN D. 2007. - When bodies remember: experiences and politics of AIDS in South Africa. University of California Press: 1-390.

FraAs O. 1870. - Die Fauna von Steinheim. Mit Rücksicht auf die miocänen Säugethier- und Vogelreste des Steinheimer Beckens. Jahreshefte des Vereins für vaterländische Naturkunde in Württemberg 26: 145-306, pl. 4-13.

GOULD S. J. 1980. - The panda's thumb: more reflections in natural history. W. W. Norton, New York \& London: 1-343.

HAY O. P. 1902. - Bibliography and catalogue of the fossil Vertebrata of North America. Bulletin of the United States geological Survey, '1901', 179: 1-868.

HeMmiNG F. 1956. - Opinion 417. Rejection for nomenclatorial purposes of volume 3 (Zoologie) of the work by Lorenz Oken entitled Okens Lehrbuch der Naturgeschichte published in 18151816. Opinions \& Declarations rendered by the International Commission on Zoological Nomenclature 14 (1): 1-42.

Herre W. 1950. - Der derzeitige Stand unseres Wissens über die fossilen Urodelen, zugleich einige kritische Bemerkungen über Boomgardia salamandriformis v. Huene. Neues Jahrbuch für Geologie und Paläontologie 1: 19-25.

HuENE F. F. VON 1948. - Ein echter Urodele aus dem unteren Dogger. Neues Jahrbuch für Geologie und Paläontologie, Monatshfete, (Abteilung B: Geologie - Paläontologie), Stuttgart: 33-39.

Joravsky D. 1970. - The Lysenko Affair. Harvard University Press, Cambridge: i-xiii + 1-459. https://doi. org/10.1177/000271627139600141

Kaiser H., Crother B. I., Kelly C. M. R., Luiselli L., O'Shea M. Ota H., Passos P., Schleip W. D. \& Wuster W. 2013. — Best practices: in the 21st century, taxonomic decisions in herpetology are acceptable only when supported by a body of evidence and published via peer-review. Herpetological Review 44 (1): 8-23.

LA CEPÈDE, [B.-G.-É. DE LA VILLE], DE 1788a. - Histoire naturelle des quadrupèdes ovipares et des serpens. [In-quarto]. Tome 1. Hôtel de Thou, Paris: [i-v] + 6-17 + 1-651, pl. 1-41, 2 tab. https:// www.biodiversitylibrary.org/page/ 40584437

LA CEPÈDE, [B.-G.-É. DE LA VILLE], DE 1788b. - Histoire naturelle des quadrupèdes ovipares et des serpens. [In-duodecimo]. Tome 1. Paris (Hôtel de Thou): 1-60 + 1-359, pl. 1-12. https://www. biodiversitylibrary.org/page/4039791

LA CePÈDE, [B.-G.-E. DE LA VILLE], DE 1788c. — Histoire naturelle des quadrupèdes ovipares et des serpens. [In-duodecimo]. Tome 2. Hôtel de Thou, Paris: [i-iv] + 1-462 + [i], pl. 1-15. https://www. biodiversitylibrary.org/page/4043628

LA CepèdE, [B.-G.-É. DE LA VILLE], DE 1789. - Histoire naturelle des serpens. [In-quarto]. Tome 2. Hôtel de Thou, Paris: [i] + 1-8 $+1-19+[\mathrm{i}]+1-144+1-527$, pl. 1-22. https://www.biodiversitylibrary.org/page/40582051

LA CEPÈDE, [B.-G.-É. DE LA VILLE], DE 1790a. - Histoire naturelle des serpens. [In-duodecimo]. Tome 3. Hôtel de Thou, Paris:1-24 + 1-432, pl. 1-11. https://www.biodiversitylibrary.org/page/4134476

LA CEPÈDE, [B.-G.-É. DE LA VILLE], DE 1790b. - Histoire naturelle des serpens. [In-duodecimo]. Tome 4. Hôtel de Thou, Paris:1-8 + 1-408, pl. 1-11. https://www.biodiversitylibrary.org/page/4040256 
Li Z., Wang W., Hu H., Wang M., Yi H. \& Lu J. 2020. — Is Oculudentavis a bird or even archosaur? bioRxiv preprint: 9 pages. https://doi.org/10.1101/2020.03.16.993949

MACKINTOSH N. (ED.) 1995. - Cyril Burt: fraud or framed? Oxford University Press, New York: 1-156.

Marcus H. 1945. - Contribución al conocimiento de los Gymnophiona XXXII. "Prohypogeophis tunariensis" (n. sp.). Un fósil de la era paleozoica. Revista de Agricultura (Bolivia) 2 (3) : 29-40. [Not seen].

Minelli A. 2003. - The status of taxonomic literature. Trends in Ecology and Evolution 18: 75-76. https://doi.org/10.1016/ S0169-5347(02)00051-4

OKeN L., VON 1816. - Lehrbuch der Naturgeschichte. Dritter Theil, Zoologie. Zweite Abtheilung, Fleischthiere. Schmid, Jena: $\mathrm{i}$-xvi + 1-1272.

SAnchíz B. 1998. - Salientia. In: P. Wellnhofer (ed.), Handbuch der Paläoherpetologie, Teil 4, Friedrich Pfeil, München: i-xii + 1-275.
Steel R. 1973. - Crocodylia. In: O. Kunn (ed.), Handbuch der Paläoherpetologie, Teil 16, Gustav Fischer, Stuttgart: i-iii + 1-116.

TATARINOV L. P. 1968. - [Discovery of a primitive caudatan amphibian in the Upper Permian of the Volga Region]. In: [Upper Paleozoic and Mesozoic amphibians and reptiles of the USSR], Akademii Nauk SSSR, Moscow: 7-10. [In Russian]. [Not seen]. VAN NoOrden R. 2011. - The trouble with retractions. Nature 478: 26-28. https://doi.org/10.1038/478026a

Xing L., O’Connor J. K., Schmitz L., Chiappe L. M., McKellar R. C., YI Q. \& G. LI G. 2020a. - Hummingbird-sized dinosaur from the Cretaceous period of Myanmar. Nature 579: 245-249. https://doi.org/10.1038/s41586-020-2068-4

Xing L., O'Connor J. K., Schmitz L., Chiappe L. M., McKellar R. C., YI Q. \& LI G. 2020b. —Corrections \& amendments. Retraction note: Hummingbird-sized dinosaur from the Cretaceous period of Myanmar. Nature, online document. https://doi. org/10.1038/s41586-020-2068-4 